МЕТАЛУРГІЯ

УДК 331.482-047.37:621.771

DOI https://doi.org/10.32838/2663-5941/2020.4/23

Тарасов B.K.

Запорізький національний університет

Воденнікова О.С.

Запорізький національний університет

Румянцев В.Р.

Запорізький національний університет

Воденнікова Л.В.

Запорізький державний медичний університет

Бабошко Д.Ю.

Криворізький національний університет

\title{
ПОШУК ШЛЯХІВ ПОКРАЩЕННЯ УМОВ ПРАЦІ В ЦЕХАХ ХОЛОДНОЇ ПРОКАТКИ
}

На прикладі цеху холодної прокатки ВАТ «Запоріжсталь» проаналізовано шкідливі та небезпечні чинники, що виникають у процесі холодної прокатки сталевих листів. Згідно з аналізом карти умов прачі в иеху холодної прокатки ВАТ «Запоріжсталь» визначено, щзо працівники цеху можуть піддаватися впливу таких факторів виробничого середовщща: запиленість; пари кислот у травильному відділенні; підвищена температура в зоні відпалу в колпакових печах; пари масти; високий рівень загальної вібрації та високий рівень виробничого шуму в прокатних відділеннях. Визначено характер та проаналізовано вплив мастильно-охолоджуючих рідин на працівників цехів холодної прокатки. Розглянуто шляхи утилізаиії мастильно-охолоджуючих рідин та зниження впливу парів у цехах холодної прокатки ВАT «Запоріжсталь». Проведено очінку рачіонального засобу захисту від негативного впливу вібрачії та шуму робочої зони иеху холодної прокатки ВАТ «Запоріжсталь» біля прокатних станів типу стан «2800», дресирувальник стан «Кварто 1680», реверсний стан «1200» та інших. Для зниження впливу вібрації в умовах прокатного виробництва запропоновано використовувати віброізоляцію, засоби індивідуального захисту та інструменти з антивібраційним покриттям контактної поверхні. Встановлено характер впливу маси установки та гранично допустимої частоти власних вертикальних коливань віброізолятора на рівень загальної вібрації. 3 метою зменшення площі небезпечної зони від дії шуму та зниження рівня звукового тиску в цехах холодної прокатки ВАТ «Запоріжсталь» доцільно встановити акустичний екран зі сталевого листа завтовшки 2 мм та шумопоглиначем із мінеральної вати. Розрахунковим шляхом встановлено зменшення площі зони впливу виробничого шуму з 297,91 $\mathrm{M}^{2}$ до 9,81 $\mathrm{M}^{2}$ та зменшення рівня шуму на 21,7 дБ, що суттєво зменшує шумове забруднення виробничого середовища. Проаналізована ефективність зниження рівня шуму в небезпечній зоні прокатного відділення залеэнно від зміни відстані від джерела шуму, показана доиільність використання відстані від джерела шуму в межах від 2 м до 6 м.

Ключові слова: умови праці, фактори виробничого середовища, прокатне відділення, мастильноохолоджуючі рідини, захист від вібрачії, захист від шуму.

Постановка проблеми. Відомо, що Україна, входячи в Топ-10 найбільших світових виробників сталі, значною мірою відстає від інших країн за застосуванням новітніх прогресивних технологій, рівнем технологічного обладнання, енергоємності прокату й екологічної безпеки [1]. 
Розглядаючи прокатне виробництво, варто зазначити, що технологія прокатного виробництва, а зокрема холодної прокатки листової сталі, характеризується високою інтенсивністю виробництва, складним комплексом технологічних операцій, застосуванням потужного механічного, електричного та термічного обладнання. Підтримка допустимих умов праці в прокатному виробництві згідно з НПАОП 27.1-1.04-09 «Про затвердження правил охорони праці в прокатному виробництві підприємств металургійного комплексу» [2] може бути досягнута шляхом дослідження величини та рівня шкідливих чинників у робочій зоні безперервного прокатного стану та розробки раціональних засобів захисту від шкідливих та небезпечних чинників виробничого середовища .

Саме тому для потреб українських металургійних підприємств необхідно удосконалити засоби захисту від шкідливих та небезпечних чинників виробничого середовища, а зокрема дослідити ефективність сучасних систем шумозахисту біля прокатних станів та уловлювання парів мастильно-охолоджуючих рідин (МОР) у цехах холодної прокатки.

Аналіз останніх досліджень і публікації. У роботі [3] проведено комплексні дослідження умов праці на всіх етапах металургійного виробництва, зокрема, починаючи від робочого місця шихтового відділення агломераційного цеху та закінчуючи робочим місцем пульту керування безперервно-заготівельним станом. Встановлено, що 75\% працівників металургійного виробництва працюють в умовах, що не відповідають гігієнічним нормативам, належать до III-го класу 3-го або 4-го ступеня шкідливості та оцінюються як шкідливі та небезпечні. Проведені дослідження доводять необхідність розробки та впровадження профілактичних заходів для покращення умов праці на металургійних підприємствах.

На жаль, шкідливі та небезпечні чинники виробничого середовища спостерігаються в різних галузях промисловості, зокрема в ливарних цехах машинобудівних підприємств [4], у ковальсько-пресовому виробництві машинобудівних підприємств [5], на підприємствах чорної металургії [6; 7], у вугільній промисловості [8], гірничо-рудній промисловості [9] та інших галузях.

За даними роботи [10], ефективність управління охороною праці в Україні має відповідати основним положенням міжнародних та державних норм (наприклад, МОП-СУОП2001. ILO-OSH 200, OHSAS 18001: 2007, SA 8000, ISO 26000 та ін.).
У роботі [11] проведена оцінка факторів професійного ризику на основі гігієнічного вивчення умов праці в електросталеплавильному та прокатному виробництвах сучасних металургійних підприємств різного рівня модернізації. Запропонована комплексна система управління професійним ризиком для здоров'я робітників металургійного виробництва та визначена ії результативність.

Проблемам професійної захворюваності в Україні та шляхам їх вирішення на сучасному етапі присвячено роботу А.В. Басанець, С.П. Краснюк, І.П. Лубянова [12].

Постановка завдання. Мета роботи - удосконалення системи заходів захисту від небезпечних та шкідливих факторів виробничого середовища в цехах холодної прокатки ВАТ «Запоріжсталь».

Для досягнення поставленої мети необхідно вирішити такі завдання:

- проаналізувати вплив небезпечних та шкідливих факторів виробничого середовища в цехах холодної прокатки ВАТ «Запоріжсталь»;

- запропонувати засоби захисту робочої зони цеху холодної прокатки ВАТ «Запоріжсталь» біля прокатних станів від впливу мастильно-охолоджуючих речовин та надмірної дії вібрації і шуму;

- оцінити вплив маси установки та гранично допустимої частоти власних вертикальних коливань віброізолятора на рівень загальної вібрації;

- проаналізувати ефективність зниження рівня шуму в небезпечній зоні прокатного відділення залежно від зміни відстані від джерела шуму.

Виклад основного матеріалу дослідження. Практичні дані умов праці на металургійних підприємствах України, зокрема в прокатних відділеннях ПАТ «АрселорМіттал Кривий Ріг», ПрАТ «МК «Азовсталь», ВАТ «Дніпропетровський металургійний завод імені Петровського», ПАТ «Дніпропетровський завод прокатних валків», ВАТ «Запоріжсталь», ПрАТ «Дніпроспецсталь», ЗАТ «Мініметалургійний завод ІСТІЛ» та інших металургійних підприємств показують, що працівники прокатного виробництва можуть піддаватися впливу парів кислот у травильному відділенні, високої температури в зоні відпалу та парів мастил, шуму та вібрації в прокатних відділеннях.

Так, за картою умов праці у відділенні прокатки і дресирування листів в умовах цеху холодної прокатки ВАТ «Запоріжсталь», на працівників впливають основні негативні та шкідливі фактори виробничого середовища: шум, вібрація та пари мастил (табл. 1). Аналіз потенційно-небезпечних та шкідливих факторів виробничого середовища 
в цеху холодної прокатки ВАТ «Запоріжсталь» показує, що умови і характер праці в цеху належать до Ш класу 3-го ступеня, робоче місце має в наявності: 1 фактор 1-го ступеня, 1 фактор 2-го ступеня, 2 фактори 3-го ступеня. За показниками робоче місце варто вважати місцем з особливо шкідливими умовами праці.

Невловлювані пари мастил, що зосереджені в робочій зоні, конденсуються природними шляхами та осідають на обладнанні та пішохідних майданчиках, що може бути причиною травм працівників у цеху від ковзання та падіння. Основною причиною виділення парів $\epsilon$ мастильно-охолоджуючі рідини (МОР), які знижують коефіцієнт тертя в процесі прокатки смуг та листів, сприяють зменшенню зносу валків і налипання металу на валки, запобіганню смуг і листів від задирів, формуванню допустимої мікрогеометрії поверхні продукції, очищенню поверхні листів від забруднень.

Небажані втрати мастил приводять до підвищення вартості готової продукції та значних втрат на їх утилізацію.

Дані роботи [13] показують, що негативний вплив МОР на працівників цеху холодної прокатки пов'язаний із потраплянням їх на шкіру та в дихальні шляхи в процесі приготування емульсії, iї розбризкування та перегріву при охолодженні смуги і листів в процесі прокатки.

Таблиця 1

Оцінка факторів виробничого середовища трудового процесу в цеху холодної прокатки ВАТ «Запоріжсталь»

\begin{tabular}{|c|c|c|c|c|c|c|}
\hline \multirow{2}{*}{$\begin{array}{c}\text { Фактори виробничого } \\
\text { середовища і трудового } \\
\text { процесу }\end{array}$} & \multirow{2}{*}{$\begin{array}{c}\text { Нормативне } \\
\text { значення } \\
\text { (ГДК) }\end{array}$} & \multirow{2}{*}{$\begin{array}{l}\text { Фактичне } \\
\text { значення }\end{array}$} & \multicolumn{3}{|c|}{$\begin{array}{c}\text { III клас - шкідливі та небезпечні } \\
\text { умови, характер праці }\end{array}$} & \multirow{2}{*}{$\begin{array}{c}\text { Час дії } \\
\text { фактора, \%, } \\
\text { за зміну }\end{array}$} \\
\hline & & & 1 ступінь & 2 ступінь & 3 ступінь & \\
\hline $\begin{array}{l}\text { Шкідливі хімічні } \\
\text { речовини, мг } \mathbf{M}^{3}: \\
\text { I клас небезпеки } \\
\text { масла мінеральні } \\
\end{array}$ & 5 & 9,2 & 1,84 & - & - & 96,6 \\
\hline $\begin{array}{l}\text { Пил переважно } \\
\text { фіброгенної дії, мг/м³ }\end{array}$ & 4 & 19,6 & - & 4,9 & - & 60,2 \\
\hline $\begin{array}{l}\text { Вібрація } \\
\text { (загальна і локальна), дБ }\end{array}$ & 109 & 121 & - & - & 12 & 95,0 \\
\hline Шум, дБА & 80 & 103 & - & - & 23 & 100 \\
\hline $\begin{array}{l}\text { Тяжкість праці, } \\
\text { напруженість праці }\end{array}$ & $\begin{array}{c}\text { середня, } \\
\text { II.б; } \\
\text { помірна }\end{array}$ & - & - & - & - & - \\
\hline $\begin{array}{l}\text { Кількість шкідливих } \\
\text { чинників }\end{array}$ & - & - & 1 & 1 & 2 & - \\
\hline
\end{tabular}

Характер та оцінка рівня впливу мастильно-охолоджуючих рідин

Таблиця 2 на працівників цеху холодної прокатки

\begin{tabular}{|c|c|c|c|}
\hline $\begin{array}{c}\text { Найменування показника оцінки } \\
\text { дії різних чинників }\end{array}$ & Рівень дії & $\begin{array}{l}\text { Кількість } \\
\text { балів }\end{array}$ & $\begin{array}{c}\text { Ступень } \\
\text { впливу }\end{array}$ \\
\hline \multirow[t]{3}{*}{ Подразнююча дія на очі } & немає впливу & 0 & $x$ \\
\hline & слабка дія & 1 & - \\
\hline & подразнююча дія & 2 & - \\
\hline \multirow[t]{3}{*}{ Шкіряно-резорбитивна } & не впливає & 0 & - \\
\hline & слабка дія & 1 & - \\
\hline & подразнююча дія & 2 & $x$ \\
\hline \multirow[t]{3}{*}{ Сенсибілізуюча } & не впливає & 0 & - \\
\hline & слабка дія & 1 & $x$ \\
\hline & подразнююча дія & 2 & - \\
\hline \multirow{4}{*}{$\begin{array}{l}\text { Токсичні речовини, що виділяються } \\
\text { в процесі експлуатації МОР }\end{array}$} & I клас небезпеки & 4 & - \\
\hline & II клас небезпеки & 3 & - \\
\hline & III клас небезпеки & 2 & - \\
\hline & IV клас небезпеки & 1 & $x$ \\
\hline
\end{tabular}


В умовах холодної прокатки листів найбільш імовірним впливом на працівників $є$ потрапляння парів мастил у дихальну систему та легені. Попадання бризок МОР на шкіру рук і обличчя малоймовірне через наявність спецодягу, але можливе в разі аварій. В умовах постійного і тривалого перебування в шкідливій зоні спостерігаються випадки алергічних реакцій, що виникають внаслідок попадання мастильна-охолоджувальної емульсії на шкіру, вдихання іiї парів і масляного туману [14].

Відпрацьовані МOP із промислових майданчиків просочуються в грунт і мігрують із підземними водами, забруднюючи водойми органічними сполуками та іншими токсичними речовинами i присадками. Ступінь впливу MOP на працівників цеху холодної прокатки та екологічну безпеку наведений у табл. 2 та табл. 3, він показує, що в цехах холодної прокатки негативний вплив парів мастил помірний, проте за умови тривалого ïх впливу підвищується вірогідність різних захворювань легенів та шкіри.

Згідно з роботою, для утилізації мастил та зниження впливу парів у цехах холодної прокатки BAT «Запоріжсталь» рекомендовано встановити вдосконалену вентиляційну систему безперервного листового стану холодного прокату, яка сприяє збільшенню кратності повітряобміну в межах 10-25 та картриджний фільтр типу NOM 112 для уловлення особливо шкідливих субмікронних часток до 0,5 мкм.

Таблиця 3

Оцінка сумарної дії шкідливих чинників парів мастильно-охолоджуючих рідин

\begin{tabular}{|c|c|c|c|}
\hline 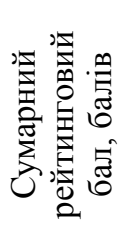 & 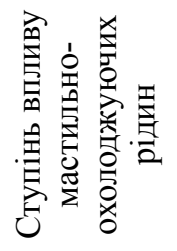 & 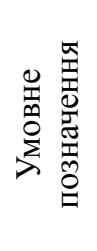 & 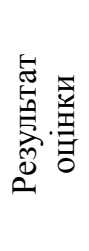 \\
\hline $\begin{array}{l}10-12 \\
\end{array}$ & Гіпер & $\Gamma \mathrm{B}$ & - \\
\hline $7-9$ & Сильний & $\mathrm{CB}$ & - \\
\hline $4-6$ & Помірний & ПВ & $\times$ \\
\hline $1-3$ & Слабкий & СлВ & - \\
\hline 0 & Без дії & БД & - \\
\hline
\end{tabular}

Сильний та тривалий вплив шуму і вібрації можуть бути причиною функціональних змін серцево-судинної і нервової систем у людини. Вібрація викликає порушення фізіологічного та функціонального станів людини.

Вплив загальної виробничої вібрації на здоров'я працівників цеху холодної прокатки має відповідати ДСТУ EN 14253:2018 [16]. Загальні вимоги до методів оцінювання шумового навантаження у виробничих приміщеннях із постійним та непостійним шумом для окремих працівників та їх груп на постійних і непостійних робочих місцях у цеху холодної прокатки мають відповідати ДСТУ 2867-94 [17].

Введення дистанційного управління технологічним обладнанням цеху повністю вирішить проблему захисту від шуму та вібрації.

Вібрація від обладнання в цехах холодної прокатки має характер стаціонарних випадкових (з основною частотою від 4 Гц до 8 Гц) і ударного типу (від 2 до 5 поштовхів на секунду за тривалості $0,05-0,3$ с) коливань.

Як методи боротьби з вібрацією на металургійному підприємстві слід використовувати індивідуальні засоби захисту (наприклад, спеціальні захисні рукавиці) та інструменти 3 антивібраційним покриттям контактної поверхні. Як колективний захід захисту від вібрації рекомендовано використовувати віброізолятор.

Сумарна жорсткість віброізоляторів у вертикальному напрямі розраховується за формулою [18]:

$$
\sum K_{6}=4 \pi^{2} f_{o d}^{2}=39,48 f_{o d}^{2} \mathrm{~m}_{0},
$$

де $\mathrm{f}_{\text {од }}$ - гранично допустима частота власних вертикальних коливань віброізолятора, Гц; $\mathrm{m}_{0}-$ сумарна маса установки, що складається 3 суми маси установки та маси рами, кг.

Якщо змінювати масу установки в діапазоні від 5 т до 10 т та варіювати значення допустимої частоти власних вертикальних коливань віброізолятора в діапазоні від 2 Гц до 8 Гц, спостерігається прамо пропорційне збільшення сумарної жорсткість віброізолятора до 32 разів (рис. 1 та рис. 2). При допустимій зоні частоти від 2 Гц до 4 Гц сумарна жорсткість віброізоляторів знаходиться в межах 789,6 Н/м до 6316,8 H/м.

У процесі пошуку засобів захисту робочої зони прокатного відділення ВАТ «Запоріжсталь» біля прокатних станів типу стан «2800», дресирувальний стан «Кварто 1680», реверсний стан «1200» та інших для зменшення площі небезпечної зони від дії шуму та зниження рівня звукового тиску запропоновано встановити акустичний екран зі сталевого листа завтовшки 2 мм та шумопоглиначем із мінеральної вати.

Згідно з табл. 1, еквівалентний рівень шуму в цеху холодної прокатки ВАТ «Запоріжсталь» становить 103 дБА, що значно перевершує допустиму норму в 80 дБА для постійних робочих 


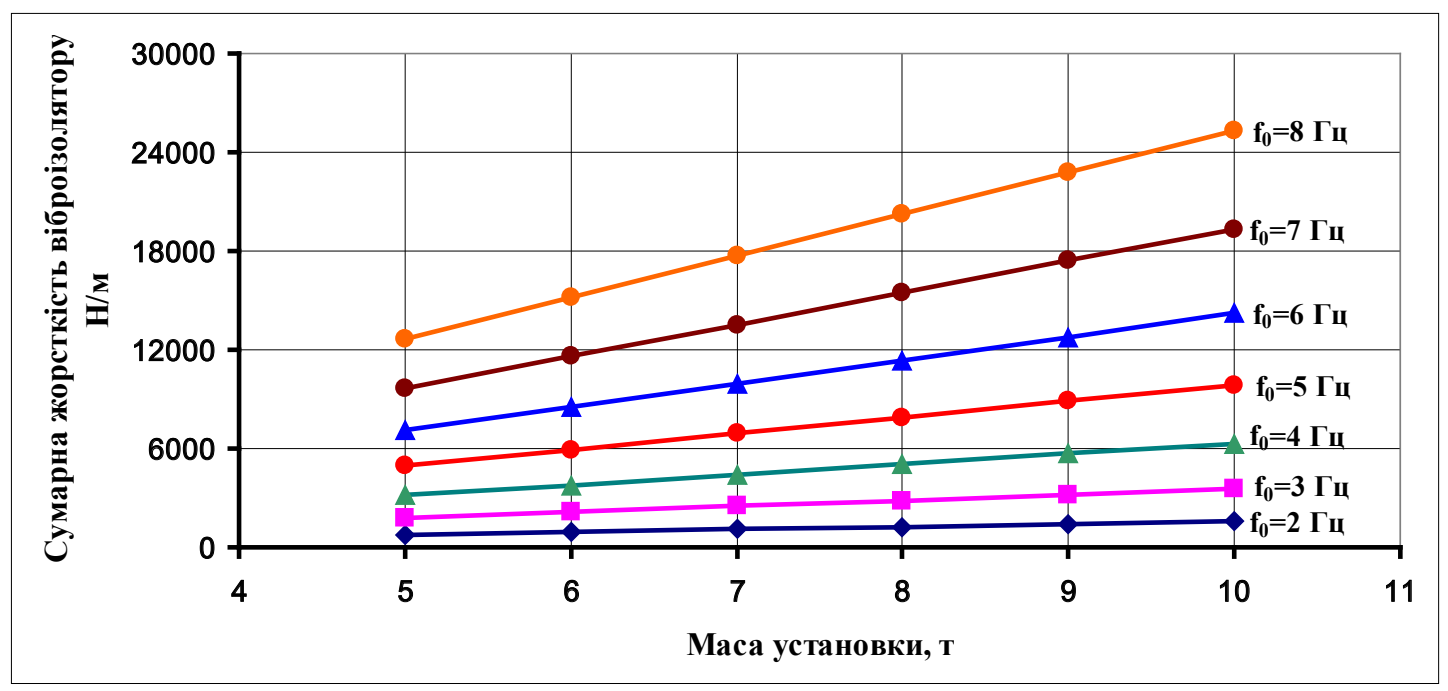

Рис. 1. Залежність сумарної жорсткості віброізолятора у вертикальному напрямі від сумарної маси установки

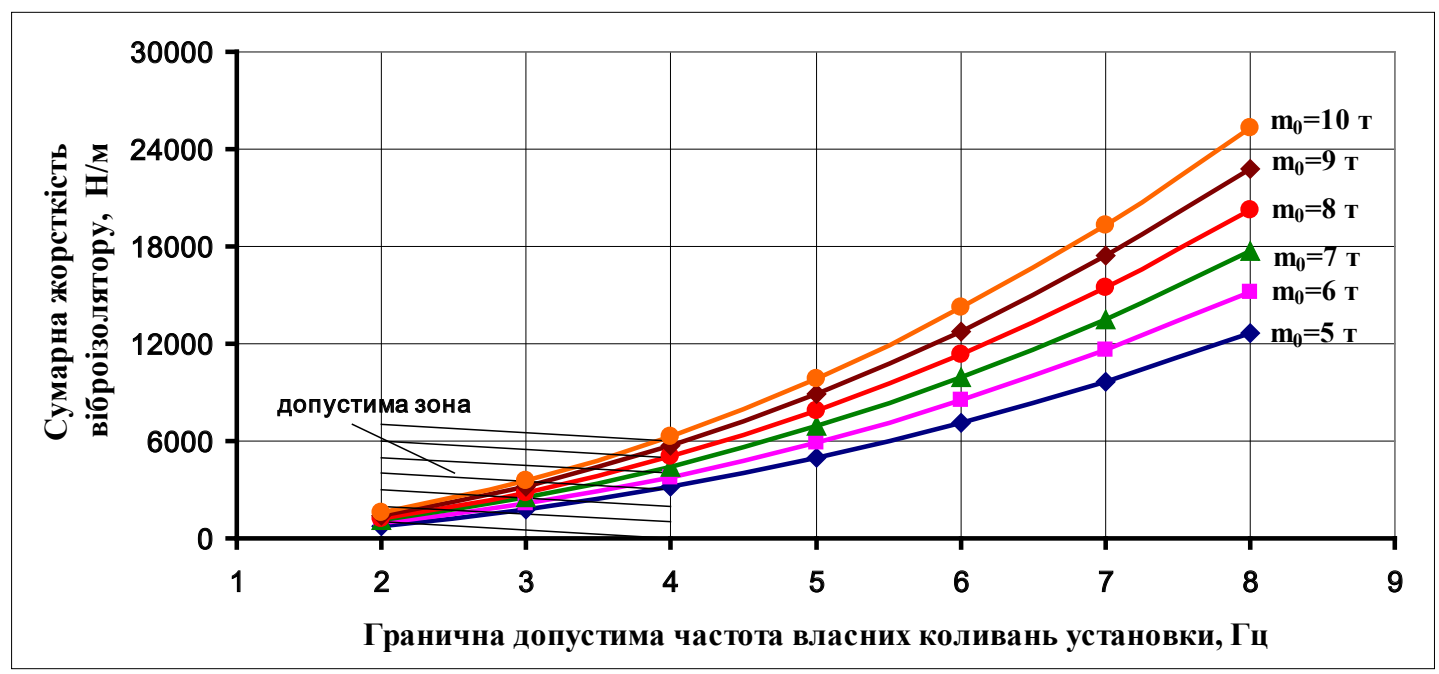

Рис. 2. Залежність сумарної жорсткості віброізолятора у вертикальному напрямі від гранично допустимої частоти власних коливань

місць. Залежно від збільшення відстані від небезпечної зони рівень шуму знижується:

$$
L_{r}=L_{1}-20 \lg r / r_{1},
$$

де $L_{l}$ - рівень шуму на відстані $r_{l}$ від джерела шуму, дБА; $r_{1}$ - рівень шуму на відстані 1 м від джерела шуму.

Знаходимо значення $r$ для допустимої норми шуму у 80 дБА:

$$
\begin{gathered}
\lg r / r_{1}=\frac{L_{1}-L_{Y}}{20}, \\
\lg r / r_{1}=\frac{103-80}{20}=1,15,
\end{gathered}
$$

Звідки значення $r$ дорівнює 14 м.

Площа небезпечної зони від дії шуму (рис. 3) буде дорівнювати:

$$
\begin{gathered}
S_{\text {ДзЗ }}=\frac{\pi \cdot r^{2}}{2}, \\
S_{\text {ДзП }}=\frac{3,14 \cdot 14^{2}}{2}=307,72 \mathrm{M}^{2} .
\end{gathered}
$$

Визначаємо зниження рівню шуму за допомогою встановлення акустичного екрана:

$$
R=L_{1}-L_{2}+10 \lg S-10 \lg \Pi,
$$

де $L_{2}$ - допустимий рівень звукового тиску, приймаємо його рівним 80 дБА;

$S$ - площа екрана, приймаємо $S=H \cdot l=$ $=3 \cdot 4=12 \mathrm{M}^{2} ; \Pi$-коефіцієнт звукопоглинання.

$$
\Pi=\frac{A}{1-\alpha},
$$

де $A$ - звукопоглинання на поверхні; $\alpha$ - середній коефіцієнт звукопоглинання матеріалів. 
Приймаючи звукопоглинання на поверхні сталі $\alpha_{\text {cmari }}=0,1$ та на поверхні мінеральної вати $\alpha_{\text {вати }}=0,69$ при частоті $f=1000$ Гц, отримуємо:

$$
\begin{gathered}
A=\left(\alpha_{C}+\alpha_{B}\right) \cdot S, \\
A=(0,1+0,69) \cdot 12=9,5 \mathrm{M}^{2} .
\end{gathered}
$$

Приймаємо середній коефіцієнт звукопоглинання матеріалів рівним:

$$
\begin{gathered}
\alpha=\frac{\alpha_{\text {сталі }}+\alpha_{\text {вати }}}{2}, \\
\alpha=\frac{0,1+0,69}{2}=0,395 .
\end{gathered}
$$

Тоді, підставляючи отримані дані у формулу (4), отримуємо:

$$
\Pi=\frac{9,5}{1-0,395}=16,3 .
$$

Зниження рівню шуму за допомогою встановлення акустичного екрана становить:

$$
\begin{aligned}
& R=103-80+10 \lg 12-10 \lg 16,3= \\
& =23+10 \cdot 1,08-10 \cdot 1,21=21,7 \partial Б .
\end{aligned}
$$

У разі встановлення акустичного екрана на відстані 2,5 м від джерела шуму, площа, обмежена екраном, становить:

$$
\begin{gathered}
S_{e k}=\frac{\pi}{2} \cdot\left(r^{2}-r_{e k}^{2}\right), \\
S_{e k}=\frac{3,14}{2} \cdot\left(14^{2}-2,5^{2}\right)=297,91 \mathrm{M}^{2} .
\end{gathered}
$$

Отже, площа небезпечної зони дорівнює:

$$
\begin{gathered}
S_{H 3}=S_{\text {дзП }}-S_{\mathrm{ek}}, \\
S_{H 3}=307,72-297,91=9,81 \mathrm{M}^{2} .
\end{gathered}
$$

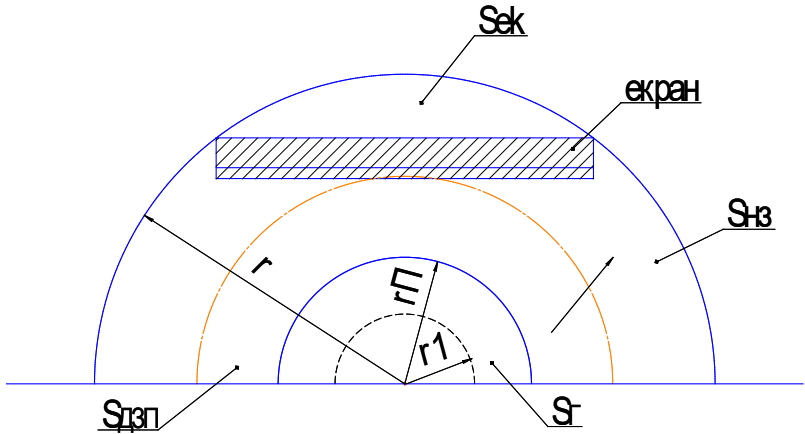

Рис. 3. Схема розрахунку площі небезпечної зони від дії шуму: $\mathrm{S}_{\mathrm{Hз}}-$ площа небезпечної зони; Sek - площа зони, що обмежена екраном; $\mathrm{S}_{\Gamma}$ - площа зони, де необхідно використати індивідуальні засоби захисту; $S_{\text {дзп }}$ - допустима зона праці після встановлення екрана; $\mathbf{r 1}$ - рівень шуму на відстані 1 м від джерела шуму; rП - радіус зони, де може працювати тільки персонал стану

Таким чином, розрахунковим шляхом встановлено зменшення площі зони впливу виробничого шуму з 297,91 $\mathrm{m}^{2}$ до 9,81 $\mathrm{m}^{2}$ та зменшення рівня шуму на 21,7 дБ, що суттєво знижує шумове забруднення виробничого середовища.

Розсіювання звуку в повітрі зменшує негативний вплив шуму на робочу зону на відстані:

$$
L_{\text {розсіования }}=10 \lg \left(R / R_{0}\right),
$$

де $\mathrm{R}$ - відстань акустичного центру джерела шуму до розрахункової точки, м; $\mathrm{R}_{0}$ - радіус джерела шуму, приймаємо рівним 1,5 м.

3 урахуванням турбулентності повітря, пов'язаного 3 роботою агрегата та руху повітря внаслідок дії витяжної вентиляції, отримуємо:

$$
\Delta L_{\text {розсіования }}^{m}=\frac{3}{1,6+10^{5}(1 / R)^{2}},
$$

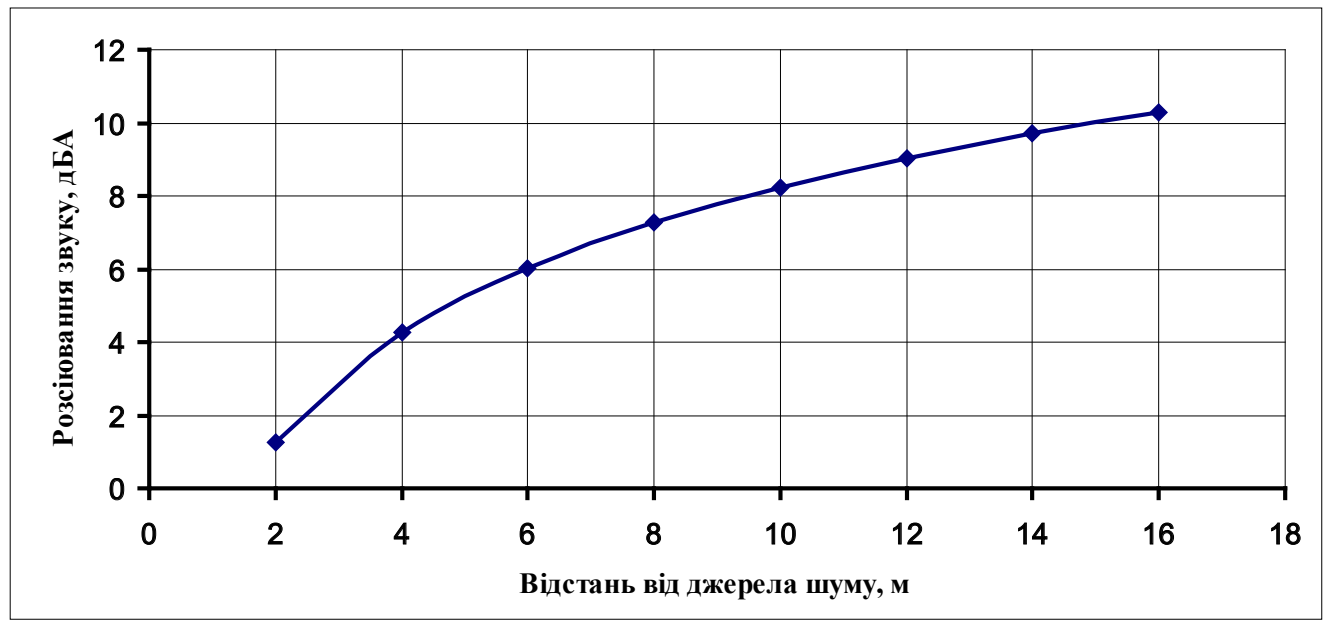

Рис. 4. Залежність розсіювання звуку від зміни відстані від джерела шуму 


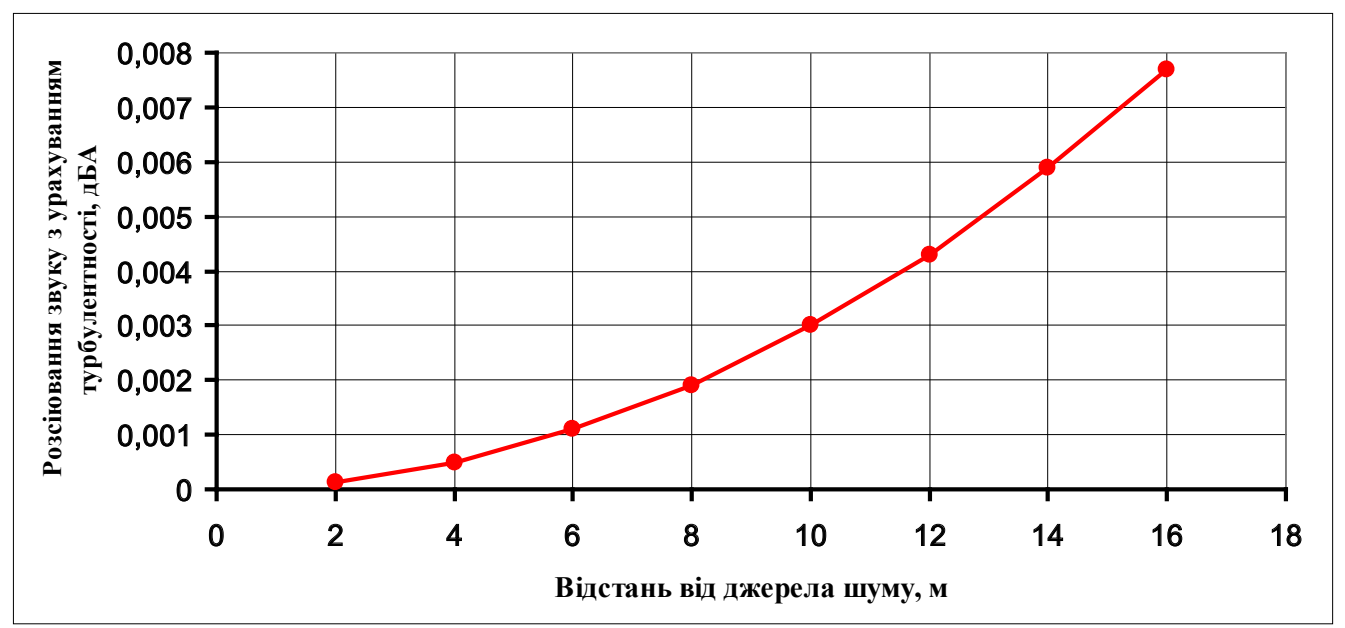

Рис. 5. Залежність розсіювання звуку з урахуванням турбулентності від зміни відстані від джерела шуму

Варіюючи значеннями відстані від джерела шуму в межах від 2 м до 16 м за формулою (9), отримуємо значення розсіювання звуку в повітрі, представлене на рис. 4. У робочій зоні, що знаходиться до 4 м до джерела шуму, спостерігається незначне розсіювання (1,6-4,1\%), проте в разі збільшення відстані до 10-16 м вплив вже сягає 7,9-10,2\%, і його необхідно враховувати при розрахунках захисних засобів.

Турбулентність повітря незначною мірою (до 0,008 дБ) впливає на розсіювання (рис. 5), тому, розраховуючи робочу витяжну вентиляцію, цей параметр варто враховувати.

Висновки. Серед шляхів покращення умов праці в цехах холодної прокатки ВАТ «Запоріжсталь» рекомендовано:
- для зниження впливу мастильно-охолоджуючих речовин на здоров'я працівників цехів холодної прокатки та навколишнє середовище підвищити ефективність вентиляційної системи безперервного листового стану холодного прокату та додатково встановити картриджний фільтр типу NOM 112;

- для зниження впливу вібрації доцільно використовувати віброізоляцію, засоби індивідуального захисту та інструменти з антивібраційним покриттям контактної поверхні;

- для зниження рівня шуму встановлення акустичного екрана зі сталевого листа завтовшки 2 мм та звукопоглиначем із мінеральної вати.

\section{Список літератури:}

1. Бізнес-портал ua.prom.info. URL: http://uaprom.info/article/5007-proizvodstvo-prokata-v-ukrainesovremennoe-sostojanie.html (дата звернення: 01.07.2020).

2. НПАОП 27.1-1.04-09. Про затвердження правил охорони праці в прокатному виробництві підприємств металургійного комплексу [Чинний від 2009-07-29]. Київ : Державний комітет 3 промислової безпеки, охорони праці та гірничого нагляду, 2009. 65 с.

3. Орєхова О.В. Сучасний стан умов праці в металургійному виробництві України. ScienceRise. Medical science. 2016. № 10. C. 34-39. URL: http://nbuv.gov.ua/UJRN/texcsrm_2016_10_8

4. Хамитова Р.Я., Лоскутов Д.В. Профессиональный риск развития болезней органов дыхания у работников литейных цехов машиностроительных предприятий. Гигиена и санитария. 2012. № 1. С. 23-26.

5. Никитин А.С. Гигиенические особенности условий труда и состояния здоровья работников современного литейного и кузнечно-прессового производств предприятия машиностроения и пути их оптимизации : дис. ... канд. мед. наук : 14.02.01 / ГОУВПО «Рязанский государственный медицинский университет». Рязань, 2011. $132 \mathrm{c}$.

6. Кошкина В.С., Антипанова Н.А., Котляр Н.Н. Мониторинг распространенности химических канцерогенов в объектах окружающей среды и биосредах у жителей города с развитой отраслью черной металлургии. Гигиена и санитария. 2006. № 1. С. 12-13.

7. Тарасов В.К., Румянцев В.Р., Новокщонова О.В., Ткаліч I.О. Розробка заходів покращення умов праці при виробництві чавуну. Вісник Київського національного університету технологій та дизайну. Серія Економічні науки. 2018. № 2 (121). С. 82-90.

8. Kirsch P. Riskgate: Industry Sharing Risk Controls Across Australian Coal Operations. Australian Journal of Multi-Disciplinary Engineering. 2014. Vol. 11. Issue 1. Pp. 47-58. 
9. Жеглова А. В. Системный подход к управлению профессиональным риском нарушений здоровья работников горнорудной промышленности : автореф. дис. ... доктора. мед. наук : 14.00.50. Москва, 2009. $48 \mathrm{c}$.

10. Зеркалов Д.В. Безпека праці : монографія. Київ : Основа, 2012. 637.

11. Егорова А.М. Системный подход к управлению профессиональным риском для здоровья рабочих металлургического производства : автореф. дис. ... доктора. мед. наук : 14.00.50. Москва, 2008. 20 с.

12. Басанец А.В., Краснюк Е.П., Лубянова И.П. Проблемы профессиональной заболеваемости в Украине и пути их решения на современном этапе. Гігієнічна наука та практика на рубежі століть : матер. XIV з’їзду гігієністів України. Дніпропетровськ, 2004. T. II. С. 38-41.

13. Молчанова 3.В. Охрана труда в прокатном производстве. Москва : Металлургия, 1973. 248 с.

14. Влияние СОЖ на здоровье человека и окружающую среду. URL: https://oilcool.ru/article/vliyanie sozh_na_cheloveka_i_okruzhayu-shchuyu_sredu/ (дата звернення: 01.07.2020).

15. Тарасов В.К., Воденнікова О.С., Куріс Ю.В., Матяшева О.Б., Воденнікова Л.В., Бабошко Д.Ю. Дослідження заходів покращення умов праці в цехах холодної прокатки. Вчені записки Таврійського національного університету імені В.I. Вернадського. Серія «Технічні науки». 2020. Т. 31(70). № 3. С. 191-196.

16. ДСТУ ЕN 14253:2018. Вібрація механічна. Вимірювання та обчислювання впливу на здоров'я загальної виробничої вібрації. Практична настанова (EN 14253:2003 + A1:2007, IDT). [Чинний від 2020-01-01]. Київ : ДП «УкрНДНЦ», 2019. 15 с.

17. ДСТУ 2867-94. Шум. Методи оцінювання виробничого шумового навантаження. Загальні вимоги [Чинний від 1996-01-01]. Київ: Держстандарт України, 1994. 32 с.

18. Курдюмов В.И. Проектирование и расчет средств обеспечения безопасности : учеб. пособие. Москва : Колос, 2005. 216 с.

\section{Tarasov V.K., Vodennikova O.S., Rumyantsev V.R., Vodennikova L.V., Babochko D.Yu. SEARCH FOR WAYS IN ORDER TO IMPROVE WORKING CONDITIONS IN COLD ROLLING SHOPS}

On the example of the cold rolling shop of JSC "Zaporizhstal" the harmful and dangerous factors that arise in the process of cold rolling of steel sheets are analyzed. According to the analysis of the map of working conditions in the cold rolling shop of JSC "Zaporizhstal" it is determined that the workers of the shop may be exposed to the following factors of the production environment: dust; acid vapors in the pickling compartment; elevated temperature in the annealing zone in hood furnaces; steam vapors; high level of general vibrations and high level of production noise in rolling mills. The nature and influence of lubricating and cooling liquids on employees of cold rolling shops are determined. Ways of utilization of lubricating and cooling liquids and reduction of influence of vapors in shops of cold rolling of JSC "Zaporizhstal" are considered. An assessment of the rational means of protection against the negative effects of vibration and noise of the working area of the cold rolling shop of JSC "Zaporizhstal" near rolling mills such as mill "2800", trainer mill "Quarto 1680", reverse mill "1200" and others. In order to reduce the impact of vibration under the conditions of rolling production, it is proposed to use vibration insulation, personal protective equipment and tools with anti-vibration coating of the contact surface. The nature of the influence of the installation mass and the maximum allowable frequency of natural vertical oscillations of the vibration isolator on the level of the general vibration is established. In order to reduce the area of the danger zone from noise and reduce the sound pressure level in the cold rolling shops of JSC "Zaporizhstal" it is advisable to install an acoustic screen made of steel sheet with a thickness of $2 \mathrm{~mm}$ and a sound absorber made of mineral wool. The reduction of the area of the industrial noise impact zone from $297,91 \mathrm{~m}^{2}$ to $9,81 \mathrm{~m}^{2}$ and the reduction of the noise level by $21,7 \mathrm{~dB}$, which significantly reduces the noise pollution of the industrial environment, have been calculated. The efficiency of noise reduction in the danger zone of the rolling mill depending on the change of distance from the noise source is analyzed and the expediency of using the distance from the noise source in the range from $2 \mathrm{~m}$ to $16 \mathrm{~m}$ is shown.

Key words: working conditions, factors of the production environment, rolling department, lubricating and cooling liquids, protection against vibration, protection against noise. 